\title{
Conservative strategy in patients with ST-segment elevation myocardial infarction
}

Strategia zachowawcza w leczeniu ostrego zawału mięśnia sercowego z uniesieniem odcinka ST

 \\ Piotr Pieniążek ${ }^{3}$ Krzysztof Żmudka ${ }^{1}$ \\ 1 Department of Hemodynamics and Angiocardiography, Institute of Cardiology, Jagiellonian University Medical College, Krakow, Poland \\ 2 Cardiovascular Intervention Center, John Paul II Hospital, Krakow, Poland \\ 3 Department of Cardiovascular Diseases, Institute of Cardiology, Jagiellonian University Medical College, Krakow, Poland
}

Post Kardiol Interw 2010; 6, 3 (21): 97-103

DOI: $10.5114 /$ pwki.2010.16349

\begin{abstract}
Background: Clinical outcomes of patients with ST-segment elevation myocardial infarction (STEMI) disqualified from an invasive strategy (InvS) are poorly understood.

Aim: To investigate the short-term result of a conservative strategy (ConS) in a real-life population of patients with STEMI.

Material and methods: 1031 patients with STEMI were retrospectively analyzed. Of these, 194 (18.8\%) patients were initially qualified to the ConS. For the remaining 837 (81.2\%) patients the InvS was applied.

Results: The most frequent reasons for disqualification from an InvS in STEMI patients were the duration of ischemia $>12 \mathrm{~h}$ (81.4\%), aborted STEMI (9.8\%) and anticipated transportation time > $2 \mathrm{~h}$ (3.1\%). On admission, in the group of InvS, cardiogenic shock was noted in $45(5.4 \%)$ patients. Death within 30 days was more frequently observed in STEMI patients who underwent ConS vs. InvS (13.9\% vs. 9.0\%, $p=0.037)$. During initial hospitalization $22(11.3 \%)$ patients who underwent ConS and $34(4.1 \%, p<0.001)$ with InvS developed symptoms of heart failure (Killip class 2-4). Age (OR 1.07 per year, $95 \% \mathrm{Cl} 1.04-1.11, p<0.0001$ ) and conservative strategy $(\mathrm{OR} 1.55,95 \% \mathrm{Cl} 0.73-4.86, p=0.035)$ were the independent predictors of death within 30 days. Moreover, in patients with InvS cardiogenic shock on admission (OR 52.4, 95\% CI 18.7-134.1, $p<0.0001)$ and in patients with ConS heart failure during hospitalization (OR 10.8, 95\% Cl 3.2-36.7, $p=0.0002$ ) independently influenced the 30-day mortality (c-statistics 0.83 ).

Conclusions: Duration of ischemia of more than $12 \mathrm{~h}$ was the main reason for disqualification from InvS. Applied ConS was associated with higher 30-day mortality when compared to InvS. The symptoms of heart failure were an independent predictor of death within 30 days in patients with ConS.
\end{abstract}

Key words: ST-segment elevation myocardial infarction, conservative strategy, percutaneous coronary intervention

\section{Streszczenie}

Wstęp: Wyniki leczenia pacjentów z zawałem serca z uniesieniem odcinka ST (STEMI) niezakwalifikowanych do strategii inwazyjnej (invasive strategy, InvS) są słabo poznane.

Cel: Ocena bezpośredniego wyniku klinicznego strategii zachowawczej (conservative strategy, ConS) zastosowanej w grupie kolejnych pacjentów ze STEMI niezakwalifikowanych do leczenia inwazyjnego.

Materiat i metody: Retrospektywnie przeanalizowano dane 1031 pacjentów ze STEMI leczonych zgodnie z obowiązującymi wytycznymi. Spośród tej grupy 194 (18,8\%) chorych zostało pierwotnie zakwalifikowanych do ConS, pozostałych 837 (81,2\%) poddano InvS.

Wyniki: Głównymi czynnikami wykluczającymi z InvS w grupie STEMI były: czas niedokrwienia > 12 godz. (81,4\%), ustąpienie bólu i zmian w EKG (9,8\%) i przewidywany czas transportu > 2 godz. (3,1\%). Przy przyjęciu 45 (5,4\%) pacjentów poddanych InvS miało objawy wstrząsu kardiogennego. Śmiertelność 30-dniowa wśród pacjentów STEMI w grupach InvS i ConS wyniosła odpowiednio 9,0\% i 13,9\% ( $p=0,037)$. Podczas pierwotnej hospitalizacji u $22(11,3 \%)$ pacjentów poddanych Cons i $34(4,1 \%, p<0,001)$ poddanych InvS pojawiły się objawy niewydolności serca (klasa 2.-4. wg Killipa). Wiek (OR 1,07 na rok, 95\% Cl 1,04-1,11, p<0,0001) i strategia zachowawcza (OR 1,55, 95\% Cl 0,73-4,86, $p=0,035)$ były niezależnymi czynnikami wystąpienia zgonu do 30. dnia w całej

Adres do korespondencji/Corresponding author:

Jarosław Zalewski MD, Centrum Interwencyjnego Leczenia Chorób Serca i Naczyń, Krakowski Szpital Specjalistyczny im. Jana Pawła II, ul. Prądnicka 80, 31-202 Kraków, tel.: +48 1261435 01, fax: +48 1261430 47, e-mail: jzalewski@szpitaljp2.krakow.pl

Praca wptynęła 7.07.2010, wersja poprawiona 10.09.2010, przyjęta do druku 11.09.2010. 
grupie. Ponadto w grupie pacjentów poddanych InvS objawy wstrząsu kardiogennego przy przyjęciu (OR 52,4, 95\% Cl 18,7-134,1, $p<0,0001)$, a w grupie pacjentów poddanych ConS objawy niewydolności serca podczas hospitalizacji (OR 10,8, 95\% Cl 3,2-36,7, $p=0,0002$ ) niezależnie determinowały 30-dniową śmiertelność (c-statystyka 0.83).

Wnioski: Najczęstszą przyczyną niezakwalifikowania chorych ze STEMI od InvS było przekroczenie czasu 12 godz. od początku bólu. Zastosowana ConS była związana z wyższą 30-dniową śmiertelnością w grupie pacjentów ze STEMI. Wśród chorych poddanych ConS wystąpienie objawów niewydolności serca niezależnie determinowało 30-dniową śmiertelność.

Słowa kluczowe: ostry zawał mięśnia sercowego z uniesieniem odcinka ST, strategia zachowawcza, przezskórna interwencja wieńcowa

\section{Introduction}

Acute coronary syndrome (ACS) is the most lifethreatening clinical manifestations of ischemic heart disease. Accurate and immediate diagnosis, individual risk stratification based on clinical situation and adequate therapy implemented in individual patient without time delays are the key points for proper and satisfactory shortand long-term results of ACS treatment [1, 2].

The whole spectrum of ACS, based on ST-T interval morphology, is divided into two, patophysiologically different categories: ST-segment elevation myocardial infarction (STEMI) [3] and non-ST-segment elevation acute coronary syndrome (NSTACS) [4]. Clinical and therapeutical approach in those two states is also different.

Primary percutaneous coronary intervention $(\mathrm{pPCl})$ is the most effective way of coronary flow restoration in STEMI patients [5], however, it requires advanced logistics and the regional coordination of health and medical care providers to reduce delay in invasive treatment, which is directly correlated with the final result of such a management strategy [6, 7]. Unfortunately not all STEMI patients receive the mechanical reperfusion therapy needed, mainly due to the elapse of a long period from the onset of ACS symptoms. Meanwhile, results of conservative therapy with pharmacological treatment only in STEMI patients initially disqualified from invasive treatment still remain unclear and poorly understood.

We sought to investigate both the reasons for disqualification from mechanical reperfusion therapy, as well as early, in-hospital and 30-day mortality in a group of consecutive, unselected STEMI patients primary qualified to receive conservative treatment. We also compared those results with STEMI patients treated invasively at the same time in our department.

\section{Material and methods}

\section{Studied group}

For the period of time from $1^{\text {st }}$ January to $31^{\text {st }}$ December 2005, physicians from 20 hospitals in Krakow and surrounding towns and emergency ambulance units submitted 1604 patients with ACS for coronary intervention to the duty doctor of the John Paul II Hospital in Krakow. This group consisted of 561 (35\%) NSTACS and 1043 (65\%) STEMI patients. Qualification for invasive treatment of myocardial infarction was performed in accordance with the current European Society of Cardiology guidelines on STEMI [8] and NSTEMI [9] management, approved by the Polish Cardiac Society. Patients with persistent ST-segment elevation or newly diagnosed left bundle branch block (LBBB) were treated with mechanical reperfusion therapy if duration of myocardial ischemia (time from chest pain onset) was less than $12 \mathrm{~h}$. In patients with cardiogenic shock the time windows were longer, up to $18 \mathrm{~h}$ from the shock onset and up to $36 \mathrm{~h}$ from the chest pain onset.

During the first telephone contact between referring physician and consulting cardiologist, the decision about following therapy in each individual case of STEMI was made. Disqualification from $\mathrm{PPCl}$ was termed conservative strategy (ConS), and in those cases pharmacotherapy was used. Reversely, a decision for immediate interventional treatment was termed invasive strategy (InvS).

Based on the above mentioned criteria out of all the 1043 STEMI cases submitted to our department, 837 patients were qualified to receive interventional treatment, and the remaining 206 patients were to receive conservative therapy alone. After an assessment of all the consultation forms for the year 2005, we asked all collaborating local departments for permission to access the medical records of those who were treated conservatively in those wards. Out of 206 patients with STEMI qualified to ConS, we were able to assess 194 (94.2\%) cases. Finally, medical records and clinical data from collaborating departments (194 patients) and the catheterization laboratory of our hospital (837 patients) were collected and analyzed. An evaluation of in-hospital stay and a 30-day follow-up in 1031 cases of STEMI was conducted. The 30-day mortality rate was estimated on the basis of data received from Lesser Poland Voivodal Registry of Citizens. The study protocol was approved by the Ethical Committee of the Jagiellonian University Medical College.

\section{Clinical observation}

The primary end-point in this study was death within a 30-day follow-up. Secondary end-points in our retrospective observation were: cardiogenic shock at the time of invasive cardiology consultation, symptoms of heart failure (Killip class 2-4) during in-hospital period, and delayed referral for coronary angiography or planned 
Table 1. Baseline characteristics

Tabela 1. Charakterystyka pacjentów

\begin{tabular}{|c|c|c|c|}
\hline & InvS & Cons & $p$ \\
\hline Age (mean \pm SD) [years] & $62.8 \pm 11.5$ & $64.6 \pm 12.9$ & NS \\
\hline Male gender $[\%(\mathrm{n} / \mathrm{N})]$ & $70.3(588 / 837)$ & $69.1(134 / 194)$ & NS \\
\hline \multicolumn{4}{|c|}{ Cardiovascular risk factors $[\%(\mathrm{n} / \mathrm{N})]$} \\
\hline hypertension & $72.5(607 / 837)$ & $72.7(141 / 194)$ & NS \\
\hline diabetes & $16.1(135 / 837)$ & $34.0(66 / 194)$ & $<0.0001$ \\
\hline dyslipidemia & $33.5(280 / 837)$ & $36.1(70 / 194)$ & NS \\
\hline smoking & $41.5(347 / 837)$ & $45.9(89 / 194)$ & NS \\
\hline Previous PCI [\% (n/N)] & $3.8(32 / 837)$ & $0.1(2 / 194)$ & 0.049 \\
\hline Previous CABG $[\%(n / N)]$ & $1.6(13 / 837)$ & 0 & NS \\
\hline Previous MI [\% (n/N)] & $15.2(127 / 837)$ & $28.9(56 / 194)$ & $<0.0001$ \\
\hline \multicolumn{4}{|c|}{ Killip class at the time of consultation [\% $(n / N)]$} \\
\hline 3 & $10.5(88 / 837)$ & $1.5(3 / 194)$ & 0.0001 \\
\hline 4 & $5.4(45 / 837)$ & 0 & - \\
\hline
\end{tabular}

InvS - invasive strategy, ConS - conservative strategy, $\mathrm{PCI}$ - percutaneous coronary intervention, CABG - coronary artery bypass surgery, $\mathrm{MI}$ - myocardial infarction

InvS - strategia inwazyjna, ConS - strategia zachowawcza, $P C l$ - przezskórna interwencja wieńcowa, CABG - pomostowanie aortalno-wieńcowe, $\mathrm{MI}$ - zawat serca

invasive diagnostics of coronary arteries after primary hospitalization.

\section{Statistical analysis}

Statistical analyses were performed with Statistica Version 6 (StatSoft, Inc.) software. Continuous variables were presented as the mean value \pm standard deviation (SD) and analyzed using the t-Student test. Categorical variables were expressed as absolute values, percentages or both, and were compared by means of chi-square or Fisher test. Multivariable logistic analysis was performed to obtain independent predictors of the 30-day mortality. The model included independent variables, such as: applied treatment strategy, age, gender, time from the onset of chest pain to the moment of invasive cardiology consultation, diabetes mellitus, hypertension, previous myocardial infarction, symptoms of cardiogenic shock at the time of invasive cardiology consultation, heart failure symptoms after the invasive cardiology consultation, pharmacotherapy during the in-hospital treatment and the referral for delayed coronary angiography. A c-statistic was calculated to evaluate the discrimination model. A $p$ value less than 0.05 was considered statistically significant.

\section{Results}

\section{Study groups characteristics}

The baseline characteristics of STEMI patients in InvS and Cons groups is shown in table 1 . There were no significant differences between both groups with regard to age, gender, arterial hypertension, dyslipidemia and smoking. Subjects with STEMI from ConS more likely had a history of previous myocardial infarction $(p<0.0001)$ and a history of diabetes $(p<0.0001)$, less likely underwent $\mathrm{PCl}$ before the analyzed event $(p=0.049)$ and manifested pulmonary congestion at the time of invasive cardiology consultation ( $p=0.0001$ ), in comparison to subjects from the InvS group. The time of ischemia in the InvS group was $4.6 \pm 5.0 \mathrm{~h}$, while in over $80 \%$ of patients from the Cons group it exceeded $12 \mathrm{~h}$. All subjects with STEMI and cardiogenic shock were qualified to InvS and composed $5.4 \%$ of the group (tab. 1).

The most frequent reasons for disqualification (tab. 2) from an InvS in STEMI patients were the time of ischemia

Table 2. Criteria of qualification to conservative strategy

Tabela 2. Kryteria kwalifikacji do strategii inwazyjnej

\begin{tabular}{|c|c|}
\hline Criterion & \\
\hline Duration of ischemia > $12 \mathrm{~h}[\%(\mathrm{n} / \mathrm{N})]$ & $81.4(158 / 194)$ \\
\hline $\begin{array}{l}\text { Aborted myocardial infarction (all patients with } \\
\text { time of ischemia less than } 12 \mathrm{~h})[\%(\mathrm{n} / \mathrm{N})]\end{array}$ & $9.8(19 / 194)$ \\
\hline Anticipated transportation time $>2 \mathrm{~h}[\%(\mathrm{n} / \mathrm{N})]$ & $3.1(6 / 194)$ \\
\hline $\begin{array}{l}\text { No consent for invasive treatment } \\
{[\%(n / N)]}\end{array}$ & $2.6(5 / 194)$ \\
\hline No arterial access [\% (n/N)] & $0.5(1 / 194)$ \\
\hline $\begin{array}{l}\text { Cardiac arrest with neurological signs of CNS } \\
\text { damage }[\%(n / N)]\end{array}$ & $1.6(3 / 194)$ \\
\hline Unknown reason $[\%(\mathrm{n} / \mathrm{N})]$ & $1.0(2 / 194)$ \\
\hline
\end{tabular}

CNS - central nervous system

CNS - ośrodkowy układ nerwowy 
Table 3. Antiplatelet and anticoagulant therapy

Tabela 3. Terapia przeciwptytkowa i przeciwzakrzepowa

\begin{tabular}{lccc} 
& InvS & Cons & $p$ \\
\hline Acetylosalicylic acid [\% (n/N)] & $98.7(820 / 831)$ & $98.4(188 / 191)$ & NS \\
\hline Clopidogrel/ticlopidine [\% (n/N)] & $93.6(773 / 826)$ & $34.6(66 / 191)$ & $<0.0001$ \\
\hline Abciximab [\% (n/N)] & $18.1(145 / 830)$ & 0 & - \\
\hline Eptifibatide [\% (n/N)] & 0 & 0 & - \\
\hline Unfractioned heparin [\% (n/N)] & $93.1(770 / 827)$ & $77.6(149 / 192)$ & NS \\
\hline Low molecular weight heparin [\% (n/N)] & $6.6(55 / 830)$ & $8.9(17 / 191)$ & NS
\end{tabular}

InvS - invasive strategy, ConS - conservative strategy

InvS - strategia inwazyjna, ConS - strategia zachowawcza

$>12 \mathrm{~h}(81.4 \%)$. Rarely was the reason for such a decision aborted STEMI (9.8\%) and anticipated transportation time $>2 \mathrm{~h}$ (3.1\%, 2 patients received thrombolytic therapy). Three $(1.6 \%)$ patients were excluded from InvS due to sudden cardiac arrest with a subsequent dysfunction of the central nervous system present during the neurological examination.

\section{Treatment}

Patients qualified for InvS significantly more often received a tienopiridine derivative antiplatelet drug (93.6\% vs. $34.6 \%, p<0.0001$ ) in comparison with the ConS group (tab. 3). Platelet GP Ilb/IIla receptor inhibitor was used only in individuals treated with $\mathrm{PCl}$, and 145 subjects from this group received abciximab. Also heparin was more widely used in patients qualified for InvS than ConS (99.7\% vs. $86.5 \%, p<0.0001$ ).

Primary coronary angioplasty was performed in $90.7 \%$ (759/837) subjects from the InvS group, 1.7\% (14/837) underwent coronary artery bypass graft surgery, and the remaining 64 (7.6\%) were treated with pharmacotherapy after coronary angiography. In 1.4\% (12/837) of cases from the InvS group who underwent $\mathrm{pPCl}$, a drug eluted stent was used during the procedure.

\section{Treatment strategy and clinical results.}

Out of the patients treated with Cons in district and regional hospitals 21 (10.8\%) patients died, 44 (22.7\%) were referred directly to the local catheterization laboratory for delayed coronary angiography and/or interventional treatment (missing data) and 129 (66.9\%) were discharged home, out of whom 20 (10.3\%) had a planned hospitalization appointment for elective coronary angiography within 3 months from the discharge date (tab. 4). In the group of 44 subjects primary qualified to ConS, and transferred for delayed invasive diagnostics to a catheterization laboratory, 4 patients died due to the development of heart failure. Following discharge from the hospital, but before the 30 days of follow-up, additional 2 deaths were reported. Overall the in-hospital mortality rate in the ConS group was $12.9 \%$, and a 30 -day mortality $13.9 \%$ (fig. 1).
In STEMI patients qualified to receive InvS, 55 (6.6\%) cases of in-hospital death were noted, 35 of those due to the rapid development of cardiogenic shock. 517 (61.8\%) patients from InvS after initial invasive treatment were transferred to other wards and department in local and district hospitals for subsequent treatment and continuation of a guideline-based pharmacotherapy. Two hundred sixty fife (31.6\%) InvS subjects were directly discharged home in good condition when reconvalescence had been completed (tab. 4). Out of 517 patients transferred to other hospitals, 18 patients died from the group (517 patients). Between discharge home and within the 30-days of follow-up, another 2 deaths were reported. In-hospital mortality was estimated and reached $8.7 \%$, whereas 30-days mortality was at the level of $9.0 \%$ and was significantly lower $(p=0.037)$ than that observed in the ConS group (fig. 1).

The mean duration of in-hospital stay completed with home discharge in the ConS group was significantly longer than it was in the case in the InvS group (mean 10.7 vs. 4.7 days, $p<0.0001$ ) (tab. 4). Symptoms and signs of heart failure in Kilip class 2-4 developed in 22 (11.3\%) patients from ConS and in 34 (4.1\%) from InvS.

Advanced age and conservative strategy were the independent predictors of the risk of death within 30 days following discharge in all subjects with myocardial infarction (tab. 4). Moreover, statistical interactions between the applied treatment strategy and symptoms of cardiogenic shock at the time of consultation, and also between implemented management and the development of heart failure already after consultation.

In the InvS group symptoms of cardiogenic shock on admission and in ConS symptoms signs of heart failure during hospitalization period were independently correlated with the 30-day mortality rate in our observation (c-statistics 0.83).

\section{Discussion}

Our study demonstrates that application of guidelines on the management of STEMI current in year 2005 was associated with a higher 30-day mortality in patients treated conservatively without initial invasive coronary 


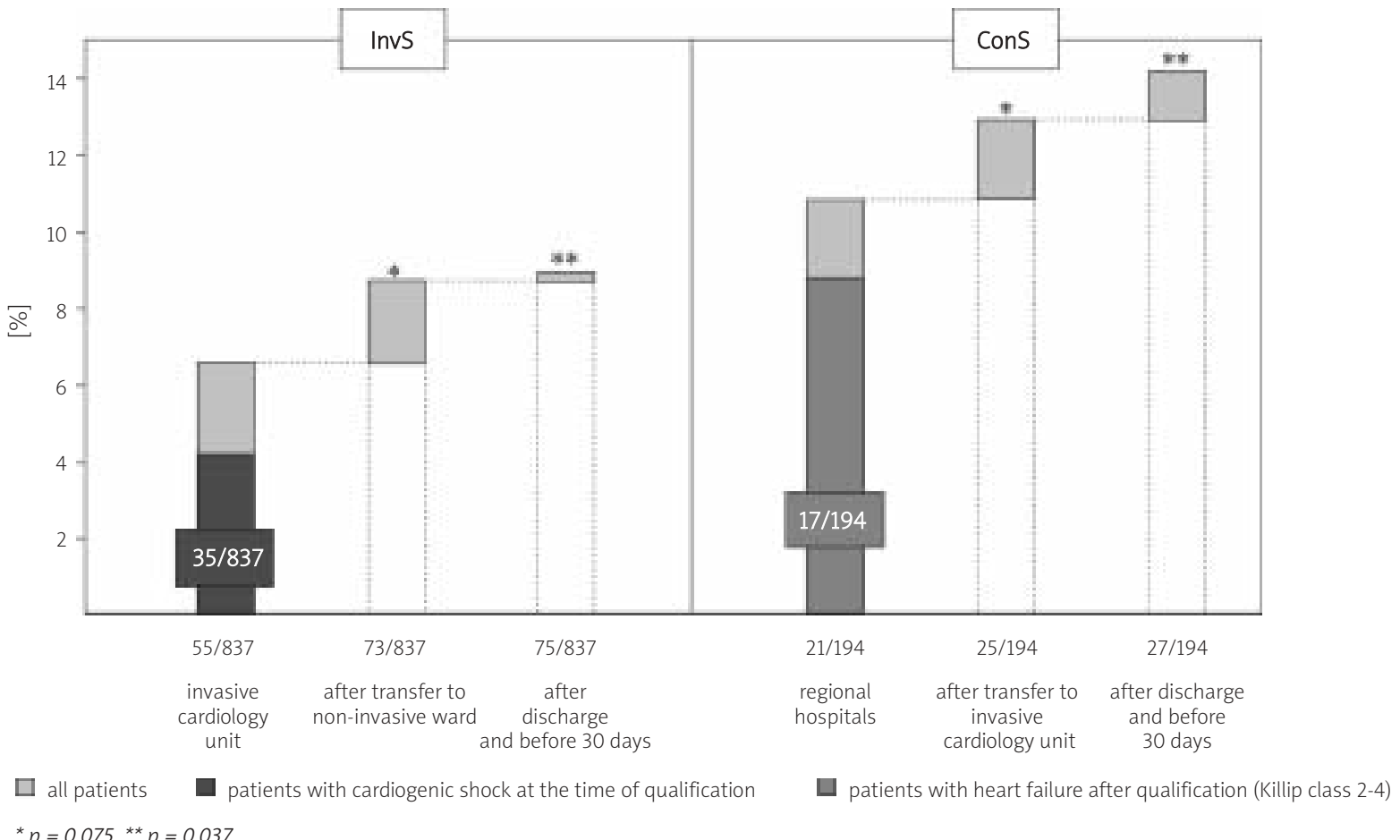

Fig. 1. 30-day mortality rate

InvS - invasive strategy, ConS - conservative strategy

Ryc. 1. Śmiertelność 30-dniowa

InvS - strategia inwazyjna, ConS - strategia zachowawcza

approach. The main aim of our study was not only an evaluation of early clinical results but also, and more importantly, a selection of potential predictors and risk factors of unfavorable clinical outcomes in STEMI patients.

In the studied STEMI group qualified to ConS in over $80 \%$ of cases duration of myocardial ischemia was greater than $12 \mathrm{~h}$. Although mechanical reperfusion therapy of
STEMI patients before $12 \mathrm{~h}$ of chest pain duration is a widely accepted and approved standard of care [1, 9], the management of those patients after that time line is rather unclear and questionable. Joint consensus of experts and medical boards, not supported by large randomized clinical trials, indicates potential benefits from coronary intervention after $12 \mathrm{~h}$ from the chest pain onset and it may

Table 4. Thirty-day clinical outcome

Tabela 4. Obserwacja 30-dniowa

\begin{tabular}{|c|c|c|}
\hline \multirow{6}{*}{$\begin{array}{l}\text { InvS } \\
N=837\end{array}$} & Hospitalization duration [day, mean \pm SD] & $4.7 \pm 3.1$ \\
\hline & Symptoms of heart failure (KK 2-4), n (\%) & $34(4.1)$ \\
\hline & Transfer to other ward, n (\%) & $517(61.8)$ \\
\hline & Discharge home, n (\%) & $265(31.6)$ \\
\hline & In-hospital mortality, n (\%) & $73(8.7)$ \\
\hline & 30-day mortality, n (\%) & $75(9.0)$ \\
\hline \multirow{6}{*}{$\begin{array}{l}\text { Cons } \\
N=194\end{array}$} & Hospitalization duration [day, mean \pm SD] & $10.7 \pm 7.9$ \\
\hline & Symptoms of heart failure (Killip class 2-4), n (\%) & $22(11.3)$ \\
\hline & Transfer to catheterization laboratory, n (\%) & $44(22.7)$ \\
\hline & $\begin{array}{l}\text { Discharge home, } \mathrm{n}(\%) \\
\text { including those patients with planned coronary angiography within } 3 \text { months from discharge date }\end{array}$ & $\begin{array}{r}129(66.5) \\
20(10.3)\end{array}$ \\
\hline & In-hospital mortality & $25(12.9)$ \\
\hline & 30-day mortality & $27(13.9)$ \\
\hline
\end{tabular}

InvS - invasive strategy, ConS - conservative strategy

InvS - strategia inwazyjna, ConS - strategia zachowawcza 
Table 5. Independent predictors of death within 30 days

Tabela 5. Niezależne czynniki ryzyka wystapienia zgonu w obserwacji 30-dniowej

\begin{tabular}{|c|c|c|c|}
\hline \multirow[t]{2}{*}{ Independent variable } & \multicolumn{3}{|c|}{ 30-day mortality } \\
\hline & OR & $95 \% \mathrm{Cl}$ & $p$ \\
\hline $\begin{array}{l}\text { Interaction of symptoms of cardiogenic shock at the time of consultation with applied treatment } \\
\text { strategy }\end{array}$ & & & $<0.0001$ \\
\hline InvS (shock vs. non-shock) & 52.4 & 18.7-134.1 & \\
\hline Age (per year) & 1.07 & 1.04-1.11 & $<0.0001$ \\
\hline $\begin{array}{l}\text { Interaction of symptoms of heart failure (Killip class 2-4) after consultation with applied treatment } \\
\text { strategy }\end{array}$ & & & 0.0002 \\
\hline InvS (HF vs. non-HF) & 1.34 & $0.49-3.38$ & \\
\hline ConS (HF vs. non-HF) & 10.8 & 3.2-36.7 & \\
\hline Treatment strategy (ConS vs. InvS) & 1.55 & $0.73-4.86$ & 0.035 \\
\hline GP IIb/IIla receptor antagonist (Y/N) & 0.86 & $0.68-1.28$ & 0.19 \\
\hline Duration of ischemia (per hour) & 1.04 & $0.98-1.16$ & 0.21 \\
\hline Clopidogrel/ticlopidine $(\mathrm{Y} / \mathrm{N})$ & 0.93 & $0.64-1.45$ & 0.27 \\
\hline Anterior wall myocardial infarction $(\mathrm{Y} / \mathrm{N})$ & 1.81 & $1.15-2.88$ & 0.28 \\
\hline Diabetes mellitus (Y/N) & 1.44 & $0.57-3.64$ & 0.44 \\
\hline Gender (M vs. F) & 0.92 & $0.39-2.16$ & 0.84 \\
\hline Previous myocardial infarction $(\mathrm{Y} / \mathrm{N})$ & 1.01 & $0.38-2.67$ & 0.98 \\
\hline
\end{tabular}

c-statistics 0.83

InvS - invasive strategy, ConS - conservative strategy, shock - cardiogenic shock, HF - heart failure, Y/N - yes/no, M - male, F - female

InvS - strategia inwazyjna, ConS - strategia zachowawcza, shock - szok kardiogenny, HF - niewydolność serca, Y/N - tak/nie, M - mężczyzna, F- kobieta

be recommended in cases of persistent clinical symptoms and/or signs in electrocardiogram indicating ongoing myocardial ischemia [1]. Additionally, currently there is a registry $[10]$ and a prospective randomized clinical trial [11] addressed to asymptomatic STEMI patients after the $12^{\text {th }} \mathrm{h}$ from the onset of this condition. Accordingly, $\mathrm{PCl}$ in STEMI patients between the $12^{\text {th }}$ and $48^{\text {th }} \mathrm{h}$ from the onset of chest pain is related to a significant reduction of the myocardial infarction area, measured in a single photon emission computed tomography between the $5^{\text {th }}$ and $10^{\text {th }}$ day $(13 \%$ vs. $8 \%, p<0.001)$. However, those results though visible in medical imaging did not improve clinical outcomes. Those observations have apparently been proved by other studies, like the sub-analysis of the OAT study [12]. It was shown that reperfusion of the occluded infarct-related artery in asymptomatic STEMI patients between the 24 and 72 hrs from the onset of myocardial ischemia symptoms was related to no clinical benefits in comparison to standard conservative therapy.

Our study is another one that reports a significantly increased mortality rate in STEMI patients treated conservatively. It is worth noting that the observed 30-days mortality rate in the ConS group with no cardiogenic shock at the time of consultation, and qualification to one of two possible strategies of management, was close to $14 \%$. That indicates that the development of heart failure already after primary consultation and therapeutic way assignment still remains an unresolved problem in the STEMI population.
Immediate diagnosis establishment, appropriate therapy introduction with no time delays and reconsideration of the invasive strategy appear to be correct, which may improve the clinical outcomes in ConS STEMI patients. Our observations based on the collected material indicates that only about $1 / 5$ of STEMI patients primary enrolled in the ConS group underwent early invasive coronary angiography, and another $10 \%$ were referred to a catheterization laboratory within 3 months of discharge home. Observations from recent years show that an increased number of catheterization laboratories and the greater availability of invasive cardiology is connected with improved treatment outcomes in STEMI patients, what has its reflection in upto-date guidelines for the management of STEMI [1].

It seems that if in STEMI patient treated in conservative way, mainly due to excessive duration of myocardial ischemia, signs and symptoms of heart failure set in, it is always worth re-consulting his treatment options and reconsidering an invasive way for the management of that state.

\section{Study limitations}

Our study has several limitations. First, it is a retrospective study of clinical consequences of risk stratification and a decision making algorithm used in the management of STEMI patients in 2005. Second, despite our extensive efforts, we were not able to collect data of $6 \%$ of patients in the conservative treatment group. Third, 
due to the different and heterogenous description criteria of ischemia recurrence and reinfarction used in many centers and the lack of an objective tool for those states with regard to a retrospective clarification, our study did not analyze either recurrent myocardial ischemia nor reinfarction in the conservative strategy group. Finally, we did not perform any kind of coronary angiography analysis in cases from the conservative strategy group referred to delayed coronary angiography in different catheterization laboratories, due to an inability to collect a sufficient amount of angiographic data, though in our opinion such an analysis could provide additional, interesting and important information and insight into the discussed problem.

\section{Conclusions}

The main reason for disqualification from invasive treatment in the presented group of STEMI patients was duration of myocardial ischemia exceeding $12 \mathrm{~h}$. Applied conservative strategy in this group of patients was independently associated with higher 30-day mortality rate when compared to invasive treatment. The symptoms of heart failure were an independent predictor of death within 30 days in patients qualified to conservative strategy.

\section{Acknowledgements}

The authors would like to thank the Heads of cardiology departments of hospitals in Krakow (J. Dietl Hospital, G. Narutowicz Hospital, S. Żeromski Hospital, L. Rydygier Hospital, MSWiA Hospital, Military Hospital), Department of Intensive Care of the $1^{\text {st }}$ Chair of General Medicine of the Jagiellonian University in Krakow, and also departments of cardiology and general medicine of hospitals in Brzesko, Bochnia, Chrzanow, Limanowa, Miechow, Myślenice, Nowy Targ, Olkusz, Oświęcim, Proszowice, Rabka, Sucha Beskidzka and Wadowice for their help in in-hospital and follow-up data collection of patients disqualified from immediate invasive treatment. Special thanks the authors of this paper would like to address to Ms Katarzyna Latała for her help and contribution in follow-up data collection form Lesser Poland Voivodal Registry of Citizens.

\section{References}

1. Fox KA, Dabbous OH, Goldberg RJ, et al. Prediction of risk of death and myocardial infarction in the six months after presentation with acute coronary syndrome: prospective multinational observational study (GRACE). BMJ 2006; 333: 1091.

2. Morrow DA, Antman EM, Charlesworth A, et al. TIMI risk score for ST-elevation myocardial infarction: a convenient, bedside, clinical score for risk assessment at presentation: an intravenous nPA for treatment of infarcting myocardium early II trial substudy. Circulation 2000; 102: 2031-2037.

3. Van de Werf F, Bax J, Betriu A, et al. Management of acute myocardial infarction in patients presenting with persistent ST-segment elevation: the Task Force on the Management of ST-Segment Elevation Acute Myocardial Infarction of the European Society of Cardiology. Eur Heart J 2008; 29: 2909-295.

4. Bassand J-P, Hamm CW, Ardissino D, et al. Guidelines for the diagnosis and treatment of non-ST-segment elevation acute coronary syndromes. Eur Heart J 2007; 28: 1598-1660.

5. Keeley EC, Boura JA, Grines CL. Primary angioplasty versus intravenous thrombolytic therapy for acute myocardial infarction: a quantitative review of 23 randomised trials. Lancet 2003; 361: 13-20.

6. Cannon CP, Gibson CM, Lambrew CT, et al. Relationship of symptom-onset-to-balloon time and door-to-balloon time with mortality in patients undergoing angioplasty for acute myocardial infarction. JAMA 2000; 283: 2941-2947.

7. Gibson CM. Time is myocardium and time is outcomes. Circulation 2001; 104: 2632-2634.

8. Van de Werf F, Ardissino D, Betriu A, et al. Management of acute myocardial infarction in patients presenting with ST-segment elevation. Eur Heart J 2003; 24: 28-66.

9. Bertrand ME, Simoons ML, Fox K, et al. Management of acute coronary syndromes in patients presenting without persistent ST-segment elevation. Eur Heart J 2002; 23: 1809-1840.

10. Cohen M, Gensini GF, Maritz F, et al. The safety and efficacy of subcutaneous enoxaparin versus intravenous unfractionated heparin and tirofiban versus placebo in the treatment of acute ST-segment elevation myocardial infarction patients ineligible for reperfusion (TETAMI): a randomized trial. J Am Coll Cardiol 2003; 42: 1348-1346.

11. Schomig A, Mehilli J, Antoniucci D, et al. Beyond $12 \mathrm{~h}$ Reperfusion AlternatiVe Evaluation (BRAVE-2) Trial Investigators. Mechanical reperfusion in patients with acute myocardial infarction presenting more than 12 hours from symptom onset: a randomized controlled trial. JAMA 2005; 293: 2865-2862.

12. Menon V, Pearte CA, Buller CE, et al. Lack of benefit from percutaneous intervention of persistently occluded infarct arteries after the acute phase of myocardial infarction is time independent: insights from Occluded Artery Trial. Eur Heart J 2009; 30: 183-191. 